\title{
Publisher Correction to: Authentic STEM research, practices of science, and interest development in an informal science education program
}

Bobby Habig ${ }^{1,2,3^{*}}$ (D) and Preeti Gupta ${ }^{1}$

\section{Correction to: IJ STEM Ed (2021) 8:57}

https://doi.org/10.1186/s40594-021-00314-y

During the publication of the original article (Habig \& Gupta, 2021) an error was introduced in the formatting of Table 1, this error has now been corrected to improve the readability of the table. This does not impact the scientific content of the table. The publisher apologizes for the inconvenience caused to the authors and readers.

\author{
Reference \\ Habig, B., \& Gupta, P. (2021). Authentic STEM research, practices of science, and \\ interest development in an informal science education program. IJ STEM \\ Ed, 8, 57. https://doi.org/10.1186/s40594-021-00314-y
}

\section{Publisher's Note}

Springer Nature remains neutral with regard to jurisdictional claims in published maps and institutional affiliations.

\author{
Author details \\ ${ }^{1}$ American Museum of Natural History, Central Park West and 79th Street, New \\ York, NY 10024, USA. ${ }^{2}$ Department of Biology, Queens College, City University \\ of New York, 65-30 Kissena Blvd., Flushing, NY 11367, USA. ${ }^{3}$ Department \\ of Natural Sciences, Mercy College, Bronx, NY, USA.
}

Published online: 11 January 2022
The original article can be found online at https://doi.org/10.1186/s40594021-00314-y.

\footnotetext{
*Correspondence: bhabig@amnh.org
}

${ }^{1}$ American Museum of Natural History, Central Park West and 79th Street, New York, NY 10024, USA

Full list of author information is available at the end of the article

\section{SpringerOpen}

(c) The Author(s) 2022. Open Access This article is licensed under a Creative Commons Attribution 4.0 International License, which permits use, sharing, adaptation, distribution and reproduction in any medium or format, as long as you give appropriate credit to the original author(s) and the source, provide a link to the Creative Commons licence, and indicate if changes were made. The images or other third party material in this article are included in the article's Creative Commons licence, unless indicated otherwise in a credit line to the material. If material is not included in the article's Creative Commons licence and your intended use is not permitted by statutory regulation or exceeds the permitted use, you will need to obtain permission directly from the copyright holder. To view a copy of this licence, visit http://creativecommons.org/licenses/by/4.0/. 